\title{
Melanite garnet-bearing nepheline syenite minor intrusion in Mawpyut ultramafic-mafic complex, Jaintia Hills, Meghalaya
}

\author{
Monoj MAItra $^{1, *}$, J S DAVID ${ }^{1}$ and S Bhaduri ${ }^{2}$ \\ ${ }^{1}$ Central Petrological Laboratories, Geological Survey of India, Kolkata 700 016, India. \\ ${ }^{2}$ Chemical Division, Eastern Region, Geological Survey of India, Kolkata, India. \\ *Corresponding author. e-mail: monojmaitra@hotmail.com
}

\begin{abstract}
Mawpyut igneous suite in Jaintia Hills of Meghalaya plateau comprises differentiated suite of ultramaficmafic rocks. The complex differs from other ultramafic-alkaline-carbonatite igneous emplacements of Shillong plateau and Mikir Hills like Jesra, Sung, Samchampi complexes, by the absence of alkalinecarbonatite rocks as major litho-units. Melanite garnet-bearing nepheline syenite, occurs as late phase minor intrusion in Mawpyut igneous complex, posseses alkaline character and shows inubiquitous relation with the host ultramafic-mafic rocks. On the other hand, this alkaline intrusive bodies of the Mawpyut igneous complex shows chemico-mineralogical resemblance with garnet-bearing nepheline syenite, ijolite litho-members of Jesra, Sung, Samchampi complexes of the region. It is interpreted that melanite garnet-bearing nepheline syenite intrusion in Mawpyut is contemporaneous with Jesra, Sung, Samchampi ultramafic-alkaline-carbonatite complexes and the host rocks of Mawpyut complex is an earlier magmatic activity possibly from a comparatively least enriched source.
\end{abstract}

\section{Introduction}

Shylhet trap volcanism along with ultramaficmafic-alkaline-carbonatite intrusions in Shillong plateau and in Mikir Hills represent a Mesozoic magmatic episode in northeastern India (Srivastava et al 2005; Sarkar et al 1992; Nambiar 1988). Amongst these, alkali igneous complexes like Sung, Jesra and Bapung of Meghalaya plateau (Chattopadhyay and Hashmi 1984; Maitra 1992; Srivastava et al 2005; Srivastava and Sinha 2007a, 2007b) and Samchampi igneous complex of Mikir Hills (Nag et al 1999; Saha et al 2010) are worth mentioning. The Mawpyut ultramafic complex (Maitra 1992; Maitra et al 2003) in Jaintia Hills of the Meghalaya plateau, represents another contemporary magmatic emplacement. So far, alkaline and carbonatite rocks are not reported from Mawpyut mafic-ultramafic complex. In this contribution, we report the occurrence of melanite garnetbearing nepheline syenite, hereafter referred as MNS, occurring dykes in the Mawpyut igneous complex. The MNS is only representative alkaline rock in the complex intrusive into the mafic rocks. We describe the petrology of the MNS and make an attempt to compare its petrological and geochemical characteristics with similar rocks belonging to the contemporaneous alkaline complexes of the region.

Keywords. Melanite garnet; nepheline syenite minor intrusion; Mesozoic magmatism; Mawpyut complex; Meghalaya plateau. 


\section{Geology}

The Meghalaya plateau is detached from the highland of peninsular India by the north trending Rajmahal-Garo Gap (Yin et al 2010). The plateau is bounded by two EW trending faults: north dipping Dawki fault to the south (Evans 1964; Biswas and Grasemann 2005) and Oldham and Brahmaputra valley fault to the north (Bilham and England 2001; Rajendran et al 2004). A series of northeast trending and locally north trending linear topographic features, also interpreted as extensional feature related to Cretaceous Gondwana break up (Gupta and Sen 1988; Kumar et al 1996; Srivastava and Sinha 2007a, 2007b) are conspicuous within the plateau.

The plateau is underlain by Precambrian gneissic complexes (1714-450 Ma, Ghosh et al 2005a, 2005b) comprising mainly by orthogneisses, granulites and amphibolites (Ghosh et al 2005a, 2005b). A younger sequence of quartzite slate and phyllite (Shillong group), experiencing lower green schist facies metamorphism (Mitra and Mitra 2001; Ghosh et al 2005b), overlies the gneissic complexes. A suite of granite plutons ( $\mathrm{Rb}-$ Sr age of 881-479 Ma) intrudes the Proterozoic orthogneisses and metasediments of the Meghalaya plateau (Ghosh et al 2005a, 2005b). The occurrence of Cretaceous ultramafic-mafic rocks has been dated 110-120 Ma (Coffin et al 2002; Srivastava et al 2005). Geochronology by $\mathrm{U}-\mathrm{Pb}$ in zircon revealed three episodes of igneous activity at ca

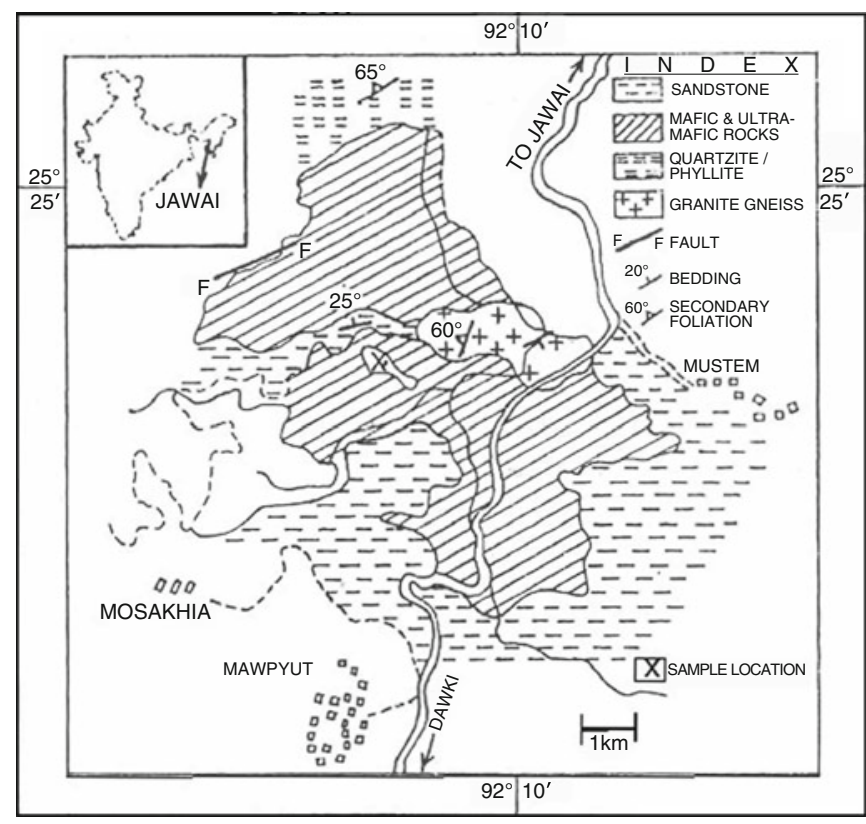

Figure 1. Geological map of the ultramafic-mafic intrusive body at Mawpyut (Maitra 1992). Inset shows overall location of the area.
$1600 \mathrm{Ma}$, ca $1100 \mathrm{Ma}$ and ca $500 \mathrm{Ma}$ and three ductile deformation events at ca 1100 , ca 520-500 Ma and during Cretaceous (Yin et al 2010).

The ultramafic-mafic complex of Mawpyut in Jaintia Hills emplaced in Archean gneisses of the eastern part of the Meghalaya plateau (Maitra 2003). It is a dome-shaped intrusive body showing oval outline in plan view (figure 1). The MNS dykes are trending $\mathrm{N} 30^{\circ} \mathrm{E}$, found in ultramaficmafic complex of Mawpyut. This intrusive body is surrounded by Precambrian granite gneiss and phyllite to the north and west and Theria sandstone of Tertiary age to the east and south. At places, chilled marginal contact and apophyses of intrusive rock are seen within the surrounding granite gneisses. The sandstone bed unconformably overlies as blanket cover on both granite gneiss and the ultramafic-mafic suite with a persistent horizon of conglomerate at its base.

\section{Petrology}

Melanite bearing nepheline syenite occurs as a minor intrusion in Mawpyut ultramafic-mafic complex. The major constituents of the rocks are nepheline, alkali feldspar, aegirine augite, melanite garnet and sphene. Modal composition of the rock (table 1) plots in the nepheline syenite field in QAPF diagram (Strekeisen 1976). The rock shows hypidiomorphic granular texture wherein the coarse-grained K-feldspar and nepheline occur as phenocryst in the rock.

Coarse-grained euhedral to subhedral nepheline shows typical alteration character. Sericitization is seen along the curvilinear cracks of nepheline grains. Nepheline composition is very consistent $\mathrm{Na}_{5.86-6.07} \mathrm{~K}_{1.54-1.66} \square_{0.36-0.55} \mathrm{Ca}_{0.01} \mathrm{Al}_{7.46-7.66}$ $\mathrm{Si}_{8.34-8.54} \mathrm{O}_{32}$ (table 2a). Coarse-grained subhedral to euhedral alkali feldspar occurs as groundmass whereas the fine-grained matrix occupied interstitial spaces of the phenocrys. Exsolution lamellae (film perthite) are occasionally seen in some grains. The alkali feldspar is hypersolvous and shows typical simple orthoclase twining (table 2a). Clinopyroxene is very coarse to medium grained, subhedral, and shows pleochroism in the shade of

Table 1. Modal analyses of melanite syenite dyke rock.

\begin{tabular}{lrcr}
\hline Sl. no. & 1 & 2 & 3 \\
\hline Alkali feldspar & 28 & 38 & 43 \\
Nepheline & 42 & 37 & 42 \\
Aegirine augite & 24 & 23 & 10 \\
Melanite garnet & 5 & 2 & 1 \\
Sphene & 1 & - & 2 \\
\hline
\end{tabular}


Table 2(a). EPMA of the K-feldspar and nepheline in nepheline syenite rocks.

\begin{tabular}{|c|c|c|c|c|c|c|c|c|c|}
\hline \multirow[b]{2}{*}{ Sample } & \multicolumn{2}{|c|}{ K- feldspar } & \multirow[b]{2}{*}{ NS } & \multirow[b]{2}{*}{ Sample } & \multicolumn{4}{|c|}{ Nepheline } & \multirow[b]{2}{*}{ NS } \\
\hline & $57 / 1$ & $73 / 1$ & & & $66 / 1$ & $67 / 1$ & $70 / 1$ & $71 / 1$ & \\
\hline $\mathrm{SiO}_{2}$ & 65.1 & 65.53 & 65.34 & $\mathrm{SiO}_{2}$ & 43.55 & 43.43 & 43.4 & 43.12 & 42.92 \\
\hline $\mathrm{Al}_{2} \mathrm{O}_{3}$ & 18.22 & 18.28 & 18.55 & $\mathrm{Al}_{2} \mathrm{O}_{3}$ & 33.71 & 32.8 & 33.39 & 33.36 & 33.60 \\
\hline $\mathrm{FeO}$ & 0.35 & 0.39 & 0.29 & $\mathrm{FeO}$ & 1.23 & 1.27 & 1.18 & 1.53 & 0.72 \\
\hline $\mathrm{MnO}$ & 0 & 0 & 0 & $\mathrm{MnO}$ & 0 & 0 & 0 & 0 & 0 \\
\hline $\mathrm{MgO}$ & 0.02 & 0 & 0.01 & $\mathrm{MgO}$ & 0 & 0 & 0 & 0 & 0 \\
\hline $\mathrm{CaO}$ & 0 & 0 & 0 & $\mathrm{CaO}$ & 0.04 & 0 & 0.05 & 0 & 0 \\
\hline $\mathrm{Na}_{2} \mathrm{O}$ & 1.88 & 1.89 & 1.86 & $\mathrm{Na}_{2} \mathrm{O}$ & 15.8 & 16.05 & 15.54 & 16.28 & 15.95 \\
\hline $\mathrm{K}_{2} \mathrm{O}$ & 14.2 & 14.25 & 13.65 & $\mathrm{~K}_{2} \mathrm{O}$ & 6.71 & 6.5 & 6.68 & 6.29 & 6.70 \\
\hline Total & 99.77 & 100.3 & 99.7 & Total & 101.0 & 100.1 & 100.2 & 100.6 & 99.89 \\
\hline $\mathrm{Si}$ & 11.00 & 12.00 & 12.00 & $\mathrm{Si}$ & 8.33 & 8.40 & 8.35 & 8.30 & 8.30 \\
\hline $\mathrm{Al}$ & 3.96 & 3.94 & 4.01 & $\mathrm{Al}$ & 7.59 & 7.46 & 7.57 & 7.56 & 7.66 \\
\hline $\mathrm{Fe}^{2}$ & 0.05 & 0.06 & 0.04 & $\mathrm{Fe}^{2}$ & 0.20 & 0.21 & 0.19 & 0.25 & 0.12 \\
\hline $\mathrm{Mn}$ & 0 & 0 & 0 & $\mathrm{Mn}$ & 0 & 0 & 0 & 0 & 0 \\
\hline $\mathrm{Mg}$ & 0.01 & 0 & 0.00 & $\mathrm{Mg}$ & 0 & 0 & 0 & 0 & 0 \\
\hline $\mathrm{Ca}$ & 0 & 0 & 0 & $\mathrm{Ca}$ & 0.01 & 0 & 0.01 & 0 & 0 \\
\hline $\mathrm{Na}$ & 0.67 & 0.67 & 0.66 & $\mathrm{Na}$ & 5.86 & 6.01 & 5.80 & 6.07 & 5.98 \\
\hline K & 3.34 & 3.33 & 3.2 & $\mathrm{~K}$ & 1.64 & 1.60 & 1.64 & 1.54 & 1.66 \\
\hline $\mathrm{Ba}$ & 0 & 0 & 0 & $\mathrm{Ba}$ & & & & & \\
\hline \multirow[t]{3}{*}{ Cations } & 20.02 & 20.01 & 19.92 & Sum_cats & 23.62 & 23.67 & 23.56 & 23.72 & 23.70 \\
\hline & & & & $\mathrm{O}$ & 32 & 32 & 32 & 32 & 32 \\
\hline & & & & $\square$ & 0.50 & 0.40 & 0.55 & 0.40 & 0.36 \\
\hline $\mathrm{X}$ & 15.954 & 15.95 & 16.012 & & & & & & \\
\hline $\mathrm{Z}$ & 4.07 & 4.061 & 3.906 & Q & 73.8 & 75.7 & 73.2 & 76.6 & 74.2 \\
\hline $\mathrm{Ab}$ & 16.8 & 16.8 & 17.1 & $\mathrm{Ne}$ & 22.9 & 20.5 & 23.0 & 20.7 & 22.8 \\
\hline An & 0 & 0 & 0 & Ks & 3.3 & 3.8 & 3.8 & 2.7 & 3.0 \\
\hline Or & 83.2 & 83.2 & 82.9 & & & & & & \\
\hline
\end{tabular}

bluish green/dark green to light brown. Extinction angle $\left(\mathrm{Z}^{\prime} \wedge \mathrm{C}\right)$ is $30^{\circ}$ and optical zoning is absent. Compositions of clinopyroxene from EPMA analyses (table $2 \mathrm{~b}$ ) fall in Non-Quad $\mathrm{Ca}-\mathrm{Na}$ pyroxenes field in respect to ' $Q$ ' and ' $J$ ' relations (Morimoto et al 1988) (figure 2) and plot in aegirine augite field (WEF - J-A diagram, after Morimoto et al 1988). Reddish pink melanite garnet shows special close relation with the alkaline pyroxene and also occurs as inclusion in it. End member composition of the garnet grains are calculated after Locock (2008) (table 3). The variation of the main compositional end members by mole\% is Andradite (64-74), Morimotoite (12-18), Schorlomites (9-11) and are almost identical composition of the melanite garnet in nepheline syenite rock of Samchampi-Samteran alkaline complex (Saha et al 2011). Titanite is euhedral, pleochroic and scattered in the rock matrix.

\section{Whole rock chemistry}

The chemical compositions of garnetiferous nepheline syenite (table 4, sl. nos. 1 and 2) plot in phonolite field in TAS diagrams (Cox et al 1979). The higher alkali content $\left(\mathrm{Na}_{2} \mathrm{O}+\mathrm{K}_{2} \mathrm{O}=14.28\right.$ wt\%) of MNS is very similar to other nepheline syenite rocks, reported from Sung and Jesra (Srivastava and Sinha 2007a, 2007b), Patcham Island (Maitra 2003) and Mundwara complex (Chakraborti 1984) (table 4). Lower Agpaitic index (A.I.=0.75) of MNS defines miaskitic character. The higher $\mathrm{K}_{2} \mathrm{O}$ content $\left(9.43\right.$ by wt\%) and $\mathrm{K}_{2} \mathrm{O} / \mathrm{Na}_{2} \mathrm{O}$ ratio (1.94) of MNS rock is similar to the nepheline syenite reported from Sung valley and Jesra in the Meghalaya plateau (Srivastava and Sinha 2007a, 2007b; Melluso et al 2010). The low $\mathrm{FeO} / \mathrm{Fe}_{2} \mathrm{O}_{3}$ ratio (0.57) in the rock can be attributed to higher $\mathrm{Fe}^{3+}$ in the pyroxene reflecting high aegirine/acmite end member and melanite garnet phases. The rock contains higher $\mathrm{SiO}_{2}$ and $\mathrm{TiO}_{2}$ in comparison to Sung and Jesra alkaline complex, respectively (Srivastava and Sinha 2007a, 2007b).

Trace element concentrations of MNS show enrichment of Large Ion Lithophile (LIL) elements particularly $\mathrm{Sr}, \mathrm{Rb}$ and $\mathrm{K}$ (table 4 ). The rocks are also enriched in High Field Strength (HFS) elements and Light Rare Earth Elements (LREE). Zr (84 ppm) and Ce (24 ppm) concentration is somewhat lower than that of Sung valley and Jesra (Srivastava and Sinha 2007b) but it is much lower 
Table 2(b). EPMA of the aegirine augite in nepheline syenite rock.

\begin{tabular}{|c|c|c|c|c|c|c|c|}
\hline \multirow[b]{2}{*}{ Sample } & \multicolumn{7}{|c|}{ Aegirine augite } \\
\hline & $58 / 1$ & $61 / 1$ & $65 / 1$ & $68 / 1$ & NS & Sung & Sung \\
\hline $\mathrm{SiO}_{2}$ & 50.78 & 49.44 & 48.47 & 49.43 & 52.72 & 50.19 & 51.62 \\
\hline $\mathrm{TiO}_{2}$ & 0.25 & 0.52 & 0.87 & 0.23 & 0.51 & 0.52 & 0.45 \\
\hline $\mathrm{Al}_{2} \mathrm{O}_{3}$ & 1.04 & 0.96 & 1.24 & 7.58 & 0.47 & 1.36 & 1.48 \\
\hline $\mathrm{FeO}$ & 26.34 & 26.49 & 25.77 & 26.26 & 6.84 & 22.61 & 19.09 \\
\hline $\mathrm{Cr}_{2} \mathrm{O}_{3}$ & 0 & 0.04 & 0.07 & 0 & 0.03 & 0 & 0 \\
\hline $\mathrm{MnO}$ & 0.98 & 1.16 & 0.99 & 0.72 & 0.38 & 0.80 & 0.76 \\
\hline $\mathrm{NiO}$ & 0.03 & 0 & 0.04 & 0.06 & 0 & 0 & 0 \\
\hline $\mathrm{MgO}$ & 1.98 & 1.56 & 1.46 & 0.86 & 9.86 & 4.01 & 5.33 \\
\hline $\mathrm{CaO}$ & 13.22 & 14.99 & 14.27 & 8.63 & 18.87 & 15.65 & 12.87 \\
\hline $\mathrm{Na}_{2} \mathrm{O}$ & 5.94 & 5.21 & 5.2 & 6.54 & 3.52 & 4.67 & 6.29 \\
\hline $\mathrm{K}_{2} \mathrm{O}$ & 0.01 & 0.01 & 0 & 0.49 & 0 & 0 & 0 \\
\hline Total & 100.6 & 100.4 & 98.38 & 100.8 & & 99.81 & 97.89 \\
\hline TSi & 1.96 & 1.93 & 1.93 & 1.88 & 1.99 & & \\
\hline $\mathrm{TAl}$ & 0.04 & 0.04 & 0.06 & 0.12 & 0.01 & & \\
\hline $\mathrm{TFe}^{3}$ & 0 & 0.03 & 0.02 & 0 & & & \\
\hline M1Al & 0.01 & 0 & 0 & 0.22 & 0.01 & & \\
\hline M1Ti & 0.01 & 0.02 & 0.03 & 0.01 & 0.01 & & \\
\hline $\mathrm{M} 1 \mathrm{Fe}^{3}$ & 0.47 & 0.44 & 0.42 & 0.39 & 0.21 & & \\
\hline $\mathrm{M}_{1 \mathrm{Fe}}{ }^{2}$ & 0.38 & 0.40 & 0.42 & 0.33 & 0.22 & & \\
\hline $\mathrm{M} 1 \mathrm{Cr}$ & 0 & 0.001 & 0.002 & 0 & 0.001 & & \\
\hline $\mathrm{M} 1 \mathrm{Mg}$ & 0.11 & 0.09 & 0.09 & 0.05 & 0.55 & & \\
\hline $\mathrm{M} 1 \mathrm{Ni}$ & 0.00 & 0 & 0.00 & 0.00 & 0 & & \\
\hline $\mathrm{M} 2 \mathrm{Mg}$ & 0 & 0 & 0 & 0 & 0 & & \\
\hline $\mathrm{M} 2 \mathrm{Fe}^{2}$ & 0 & 0 & 0 & 0.12 & 0 & & \\
\hline $\mathrm{M} 2 \mathrm{Mn}$ & 0.03 & 0.04 & 0.03 & 0.02 & 0.01 & & \\
\hline $\mathrm{M} 2 \mathrm{Ca}$ & 0.55 & 0.63 & 0.61 & 0.35 & 0.76 & & \\
\hline $\mathrm{M} 2 \mathrm{Na}$ & 0.44 & 0.39 & 0.40 & 0.48 & 0.23 & & \\
\hline Sum_cat & 4 & 4 & 4 & 3.98 & 4 & & \\
\hline $\mathrm{Q}$ & 1.04 & 1.12 & 1.12 & 0.85 & 1.53 & & \\
\hline $\mathrm{J}$ & 0.89 & 0.79 & 0.80 & 0.97 & 0.46 & & \\
\hline WEF & 54.76 & 59.44 & 58.93 & 47.52 & 77.14 & & \\
\hline JD & 0.53 & 0 & 0 & 19.24 & 0.08 & & \\
\hline $\mathrm{AE}$ & 44.70 & 40.56 & 41.07 & 33.24 & 22.06 & & \\
\hline
\end{tabular}

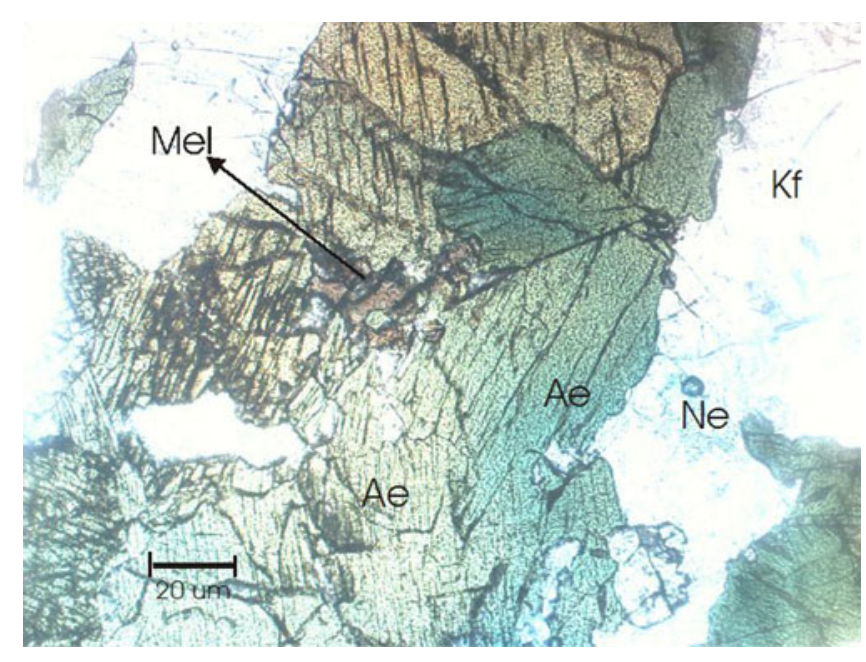

Figure 2. Photo micrograph shows melanite garnet (Mel) occurs in interstitial spaces of coarser aegirine augite grains (Ae). Kf: K-feldspar, Ne: nepheline. in respect to nepheline syenite rock of Patcham Island (Maitra 2003). The trace element ratios $\mathrm{K} / \mathrm{Rb}$ (343), K/Ba (36) and $\mathrm{Zr} / \mathrm{Y}$ (9.33) of the MNS dyke rock of the present study are similar to OIB K/Rb (387), K/Ba (34) and $\mathrm{Zr} / \mathrm{Y}$ (9.6) respectively (Sun and Mc Donough 1989). Lower $\mathrm{Zr} / \mathrm{Nb}$ ratio (0.84) of the Mawpyut dyke rock in comparison with OIB (Zr/Nb 5.8 after Sun and Mc Donough 1989) indicates its link to the deep mantle source.

\section{Discussion}

The petrography of the coarse-grained MNS indicates slow crystallization of the intrusive magma within the host mafic-ultramafic rocks in the Mawpyut igneous complex. Electron Probe Micro 
Table 3. EPMA of the melanite garnet in nepheline syenite rock Mawpyut, Samchampi and Sung igneous complex.

\begin{tabular}{|c|c|c|c|c|c|c|c|c|}
\hline \multirow[b]{2}{*}{ Sl. no. } & \multicolumn{5}{|c|}{ Mawpyut } & \multicolumn{2}{|c|}{ Samchampi } & \multirow{2}{*}{$\begin{array}{c}\text { Sung } \\
8\end{array}$} \\
\hline & 1 & 2 & 3 & 4 & 5 & 6 & 7 & \\
\hline Sample & $59 / 1$ & $60 / 1$ & $62 / 1$ & $63 / 1$ & $64 / 1$ & 4 & 5 & SV83 \\
\hline $\mathrm{SiO}_{2}$ & 33.70 & 33.35 & 33.22 & 33.40 & 33.20 & 32.09 & 32.29 & 32.91 \\
\hline $\mathrm{TiO}_{2}$ & 5.62 & 7.50 & 5.21 & 6.77 & 7.01 & 7.10 & 6.66 & 6.84 \\
\hline $\mathrm{ZrO}_{2}$ & & & & & & & & 0.17 \\
\hline $\mathrm{Al}_{2} \mathrm{O}_{3}$ & 0.72 & 0.66 & 0.67 & 0.56 & 0.53 & 0.67 & 0.71 & 1.10 \\
\hline $\mathrm{Cr}_{2} \mathrm{O}_{3}$ & 0.13 & & & 0.05 & 0.01 & 0.10 & 0.08 & \\
\hline $\mathrm{V}_{2} \mathrm{O}_{3}$ & & & & & & & & 0.45 \\
\hline $\mathrm{FeO} / \mathrm{FeO}_{\text {tot }}$ & 26.08 & 25.50 & 25.69 & 25.25 & 25.09 & 1.83 & 1.63 & 23.58 \\
\hline $\mathrm{Fe}_{2} \mathrm{O}_{3} /$ calc & & & & & & 24.83 & 25.37 & \\
\hline $\mathrm{MnO}$ & 0.74 & 0.56 & 0.77 & 0.72 & 0.71 & 0.55 & 0.58 & 0.58 \\
\hline $\mathrm{MgO}$ & 0.12 & 0.10 & 0.06 & 0.06 & 0.11 & 0.24 & 0.21 & 0.22 \\
\hline $\mathrm{CaO}$ & 31.74 & 31.64 & 30.98 & 31.51 & 31.23 & 31.53 & 31.52 & 32.05 \\
\hline $\mathrm{Na}_{2} \mathrm{O}$ & 0.27 & 0.37 & 0.33 & 0.41 & 0.36 & 0.33 & 0.35 & 0.27 \\
\hline Total (calc) & 99.12 & 99.68 & 96.93 & 98.73 & 98.25 & 99.27 & 99.40 & 98.17 \\
\hline \multicolumn{9}{|c|}{ Recalculated (wt\%) } \\
\hline Final FeO & 2.47 & 3.63 & 2.30 & 2.92 & 3.41 & 1.83 & 1.63 & 2.31 \\
\hline Final $\mathrm{Fe}_{2} \mathrm{O}_{3}$ & 26.24 & 24.31 & 25.99 & 24.82 & 24.10 & 24.83 & 25.37 & 23.64 \\
\hline Final MnO & 0.74 & 0.56 & 0.77 & 0.72 & 0.71 & 0.55 & 0.58 & 0.58 \\
\hline Final $\mathrm{Mn}_{2} \mathrm{O}_{3}$ & 0.00 & 0.00 & 0.00 & 0.00 & 0.00 & 0.00 & 0.00 & 0.00 \\
\hline Total & 101.7 & 102.1 & 99.53 & 101.2 & 100.7 & 99.27 & 99.40 & 100.5 \\
\hline \multicolumn{9}{|l|}{ End-members } \\
\hline Kimzeyite & & & & & & & & $0.35 \%$ \\
\hline Schorlomite & $6.09 \%$ & $8.30 \%$ & $5.26 \%$ & $7.44 \%$ & $7.60 \%$ & $9.73 \%$ & $8.90 \%$ & $6.27 \%$ \\
\hline Schorlomite-Al & $3.53 \%$ & $3.23 \%$ & $3.36 \%$ & $2.76 \%$ & $2.63 \%$ & $3.37 \%$ & $3.56 \%$ & $5.10 \%$ \\
\hline Morimotoite & $11.62 \%$ & $17.84 \%$ & $10.67 \%$ & $15.58 \%$ & $18.06 \%$ & $13.06 \%$ & $11.61 \%$ & $16.10 \%$ \\
\hline NaTi garnet & $2.18 \%$ & $2.98 \%$ & $2.72 \%$ & $3.33 \%$ & $2.94 \%$ & $2.73 \%$ & $2.89 \%$ & $2.20 \%$ \\
\hline Morimotoite-Mg & & & & & & $0.73 \%$ & $0.33 \%$ & \\
\hline Goldmanite & & & & & & & & $1.52 \%$ \\
\hline Uvarovite & $0.43 \%$ & & & $0.17 \%$ & $0.03 \%$ & $0.34 \%$ & $0.27 \%$ & \\
\hline Andradite & $72.05 \%$ & $63.48 \%$ & $73.98 \%$ & $67.15 \%$ & $64.60 \%$ & $67.95 \%$ & $70.26 \%$ & $66.12 \%$ \\
\hline Calderite & $1.74 \%$ & $1.31 \%$ & $1.85 \%$ & $1.70 \%$ & $1.69 \%$ & $1.32 \%$ & $1.39 \%$ & $1.38 \%$ \\
\hline Skiagite & $1.87 \%$ & $2.45 \%$ & $1.90 \%$ & $1.62 \%$ & $1.98 \%$ & & & $0.05 \%$ \\
\hline Khoharite & $0.50 \%$ & $0.41 \%$ & $0.25 \%$ & $0.25 \%$ & $0.46 \%$ & $0.71 \%$ & $0.76 \%$ & $0.92 \%$ \\
\hline Total & $100.01 \%$ & $100.00 \%$ & $99.99 \%$ & $100.00 \%$ & $99.99 \%$ & $100.00 \%$ & $99.98 \%$ & $100.01 \%$ \\
\hline Quality index & Superior & Superior & Superior & Superior & Superior & Superior & Superior & Superior \\
\hline
\end{tabular}

Analyses (EPMA) reveal that nepheline composition in the MNS rock varies from $\mathrm{Ne}_{73} \mathrm{Ks}_{23} \mathrm{Q}_{4}$ to $\mathrm{Ne}_{77} \mathrm{Ks}_{20} \mathrm{Q}_{3}$ which is very close to 'Morozewicz convergence field'. It also indicates a slow cooling in sub-solvous condition with the associated orthoclase. The melanite garnet composition in MNS is mainly a solid-solution of andradite, schorlomite and morimotoite and this composition is akin to many alkaline igneous complexes in India and different parts of the world (Bindi et al 1999; Gawalani et al 2000; Melluso et al 2010; Saha et al 2011). The constituting silicate minerals of ultramafic-mafic rocks of Mawpyut igneous complex, are mainly plagioclase, quad pyroxenes, olivine and phlogopite (Maitra et al 2003) whereas the constituting minerals (as described earlier) are different in MNS dyke rock suggesting a different melt composition.

The mafic-ultramafic rocks and the associated fine veins of syenite-monzonite (table 4 , sl. nos. 6 and 7) reported by Choudhuri et al (2009), plot in sub-alkaline field in TAS diagram (figure 3, after Irvine and Barager 1971); in the same diagram MNS rock along with garnet-bearing nepheline syenite and ijolite rocks of Sung and Jesra, plot in the alkaline field. Moreover, the MNS shows close compositional proximity with the rocks of alkaline complexes (figure 3) even from monzonite rock of the Mawpyut complex (Choudhuri et al 2009). The Chondrite (Taylor and McLennan 1985) 
Table 4. Major and trace element analyses of some selected rocks.

\begin{tabular}{|c|c|c|c|c|c|c|c|}
\hline $\begin{array}{l}\text { Sl. no. } \\
\text { Sample }\end{array}$ & $\begin{array}{c}1 \\
46 / \mathrm{Maw}\end{array}$ & $\begin{array}{c}2 \\
45 \mathrm{~A}\end{array}$ & 3 & $\begin{array}{c}4 \\
\mathrm{Av} / \mathrm{Jas}\end{array}$ & $\begin{array}{c}5 \\
\text { Av/Sung }\end{array}$ & $\begin{array}{c}6 \\
32 / \mathrm{m} / \mathrm{Maw}\end{array}$ & $\begin{array}{c}7 \\
\text { J1/ocp/Maw }\end{array}$ \\
\hline $\mathrm{SiO}_{2}$ & 57.34 & 55.98 & 56.90 & 52.32 & 52.55 & 53.61 & 49.1 \\
\hline $\mathrm{TiO}_{2}$ & 0.46 & 0.13 & 0.29 & 1.68 & 0.69 & 2.81 & 0.58 \\
\hline $\mathrm{Al}_{2} \mathrm{O}_{3}$ & 18.97 & 20.01 & 23.40 & 17.73 & 19.03 & 15.52 & 2.11 \\
\hline $\mathrm{Fe}_{2} \mathrm{O}_{3}$ & 2.98 & 1.65 & 1.10 & 7.42 & 5.93 & - & 0 \\
\hline $\mathrm{FeO}$ & 1.71 & 3.33 & 2.61 & 0 & 0 & 8.5 & 5.7 \\
\hline $\mathrm{MnO}$ & 0.13 & 0.14 & 0.01 & 0.11 & 0.12 & 0.14 & 0.09 \\
\hline $\mathrm{MgO}$ & 0.2 & 0.05 & 0.52 & 1.58 & 7 & 3.77 & 19.79 \\
\hline $\mathrm{CaO}$ & 1.87 & 2.06 & 1.12 & 4.6 & 3.03 & 8.18 & 20.42 \\
\hline $\mathrm{Na}_{2} \mathrm{O}$ & 4.85 & 8.21 & 8.15 & 3.92 & 8.81 & 3.12 & 0.28 \\
\hline $\mathrm{K}_{2} \mathrm{O}$ & 9.43 & 6.46 & 4.58 & 6.76 & 5.91 & 1.96 & 0.04 \\
\hline $\mathrm{P}_{2} \mathrm{O}_{5}$ & 0.03 & 0.10 & 0.02 & 0.42 & 0.16 & 0.46 & 0.01 \\
\hline LOI & 0.93 & 1.54 & 0.42 & 2.3 & 2.21 & 0.06 & 0.71 \\
\hline Total & 98.9 & 99.66 & 99.12 & 98.84 & 105.44 & 98.13 & 98.83 \\
\hline $\mathrm{K}$ & 78281 & 53605 & - & 56117 & 49061 & 16271 & 332 \\
\hline $\mathrm{Ba}$ & 2176 & 450 & - & 2541 & 1288 & 406 & 54 \\
\hline $\mathrm{Rb}$ & 228 & 100 & - & 135 & 113 & 55 & 8 \\
\hline $\mathrm{Sr}$ & 571 & 165 & - & 3666 & 589 & 501 & 105 \\
\hline $\mathrm{Nb}$ & 100 & 48 & - & 94 & 83 & 26 & 5 \\
\hline $\mathrm{Ta}^{*}$ & 6 & 3 & - & 6 & 5 & - & 0.3 \\
\hline $\mathrm{Zr}$ & 84 & 157 & - & 511 & 307 & 261 & 32 \\
\hline $\mathrm{Ti}$ & 2758 & - & - & 10072 & 4137 & 16846 & 3477 \\
\hline $\mathrm{Y}$ & 9 & - & - & 24.5 & 12 & 33 & 11 \\
\hline Th & 3 & 5.1 & - & 16.9 & 2.6 & 6 & - \\
\hline $\mathrm{U}$ & & - & - & 4.5 & 1.4 & - & - \\
\hline $\mathrm{V}$ & 115 & - & - & 140 & 170 & - & - \\
\hline
\end{tabular}

$\mathrm{Nb}=17 \times \mathrm{Ta}^{*}$ (Wilson 1989). 1. MNS of Mawpyut, 2. nepheline syenite in Patcham Island (Maitra 2003), 3. nepheline syenite of Mundwara alkaline complex (Chakraborty 1984), 4 and 5. average nepheline syenite of Jesra and Sung (Srivastava and Sinha 2007a, 2007b), 6 and 7. monzonite, olivine clinopyroxene of Mawpyut (Chaudhuri et al 2009).

Table 5. REE concentration of melanite nepheline syenite rocks.

\begin{tabular}{lcrr}
\hline Sample & 1 & 2 & \multicolumn{1}{c}{3} \\
& $46 / \mathrm{Maw}$ & $1 / \mathrm{Jes}$ & $1 / \mathrm{Sung}$ \\
\hline $\mathrm{La}$ & 8.37 & 17 & 8.8 \\
$\mathrm{Ce}$ & 24.19 & 29.8 & 29.2 \\
$\mathrm{Pr}$ & - & 3.44 & 4.36 \\
$\mathrm{Nd}$ & 11.22 & 12.2 & 16.8 \\
$\mathrm{Sm}$ & 2.24 & 2.2 & 2.9 \\
$\mathrm{Eu}$ & 0.92 & 0.53 & 0.81 \\
$\mathrm{Gd}$ & 0.64 & 1.8 & 2.2 \\
$\mathrm{~Tb}$ & 0.08 & 0.3 & 0.3 \\
$\mathrm{Dy}$ & - & 1.7 & 1.6 \\
$\mathrm{Ho}$ & 0.05 & 0.3 & 0.3 \\
$\mathrm{Er}$ & - & 0.9 & 0.7 \\
$\mathrm{Tm}$ & - & 0.13 & 0.1 \\
$\mathrm{Yb}$ & 0.17 & 0.9 & 0.9 \\
$\mathrm{Lu}$ & 0.05 & 0.17 & 0.17 \\
$(\mathrm{La} / \mathrm{Yb})_{\mathrm{N}}$ & 32.92 & 12.86 & 6.61 \\
$(\mathrm{La} / \mathrm{Sm})_{\mathrm{N}}$ & 2.81 & 3.27 & 2.43 \\
$(\mathrm{Gd} / \mathrm{Yb})_{\mathrm{N}}$ & 3.01 & 1.61 & 1.98 \\
\hline
\end{tabular}

1. MNS dyke rocks of Mawpyut complex. 2 and 3. Jesra and Sung valley alkaline complex of Shillong Plateau.

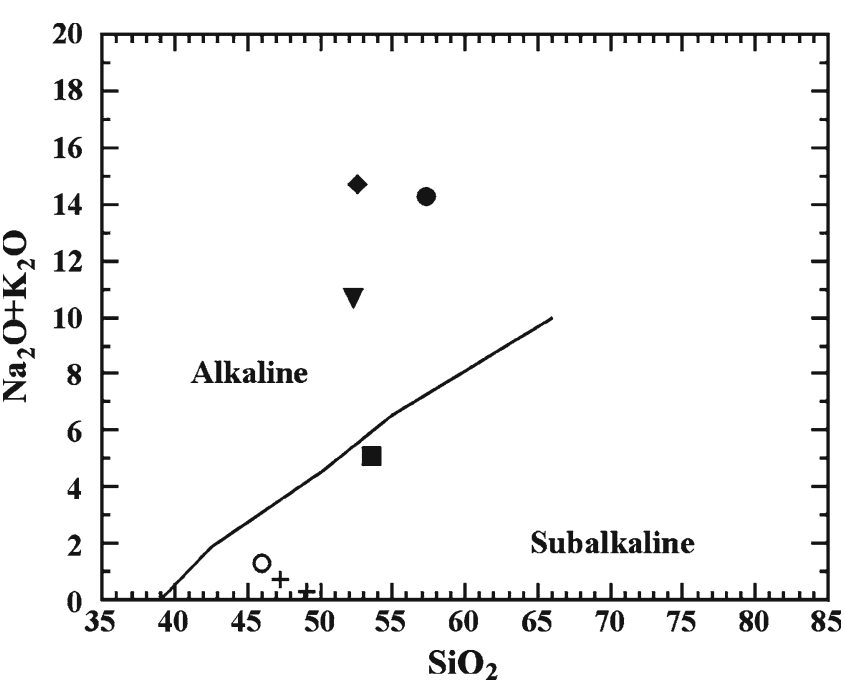

Figure 3. Plots of representative rocks of the Mawpyut, Sung, Samchampi and Jesra complexes in TAS diagram (after Irvine and Barager 1971), for comparison. @: Melanite garnet bearing nepheline syenite, $\bigcirc$ : gabbro (Maitra et al 2003 ) +: pyroxenite and olivine clinipyroxenite (Maitra et al 2003 and Chaudhuri et al 2009 respectively) and $\mathbf{\square}$ : Monzonite (Chaudhuri et al 2009), in Mawpyut complex. Average nepheline syenite composition $\diamond$ : in Sung Valley and $\mathbf{\nabla}$ : in Jesra ultramafic alkaline carbonatite complex (Srivastava and Sinha 2007b). 


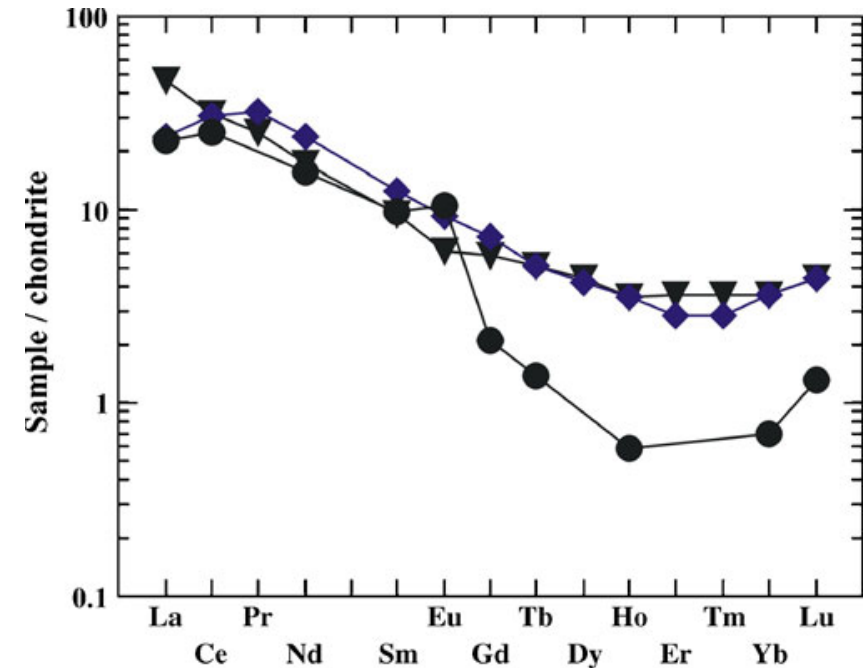

Figure 4. Chondrite normalized (Taylor and McLennan 1985) REE diagram (for explanation, see text and table 5). -: Melanite garnet bearing nepheline syenite, Nepheline syenite composition $\boldsymbol{\nabla}$ : in Sung Valley and $\mathbf{\nabla}$ : in Jesra ultramafic alkaline carbonatite complex (Srivastava and Sinha 2007a, 2007b).

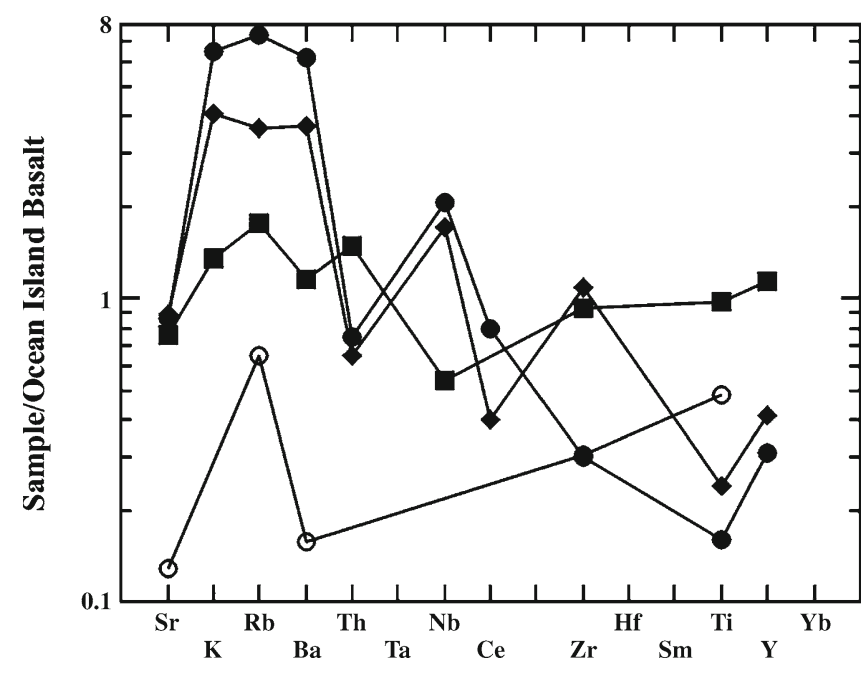

Figure 5. OIB normalized (Mc Donough 1989) multielement variation diagram (for explanation see text). Symbols are same as in figure 3 .

normalized REE diagram (figure 4) shows similar LREE fractionation $\left[(\mathrm{La} / \mathrm{Sm})_{\mathrm{N}}=2.8\right]$ pattern of the MNS rock in comparison to that of Sung valley and Jesra alkaline complex (2.43 and 3.47 respectively, table 5). However, the highly fractionated HREE $\left[(\mathrm{Gd} / \mathrm{Yb})_{\mathrm{N}}=3\right]$ of MNS rock indicating parental melt of MNS rock derived from a source of HREE rich phases in residue.

Besides major and REE trace element chemistry, OIB normalized multi-element variation diagram (Sun and Mc Donough 1989) revealed a different trend between the gabbro (Maitra 2003) and MNS rock of the complex. Interestingly, the monzonite

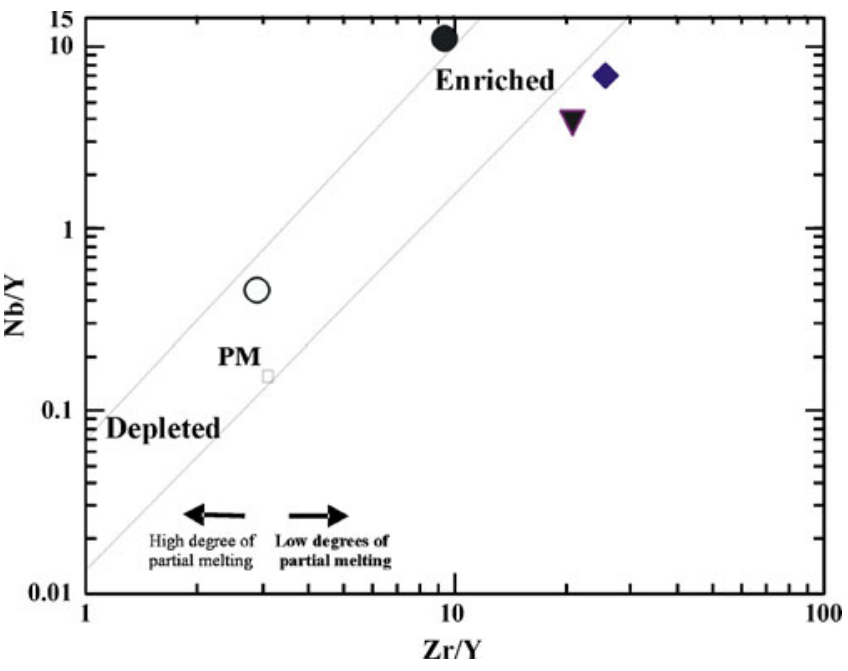

Figure $6 . \mathrm{Nb} / \mathrm{Y}$ vs. $\mathrm{Zr} / \mathrm{Y}$ plot showing sources close to the enriched mantle (Riley et al 2005). Symbols are same as in figure 3.

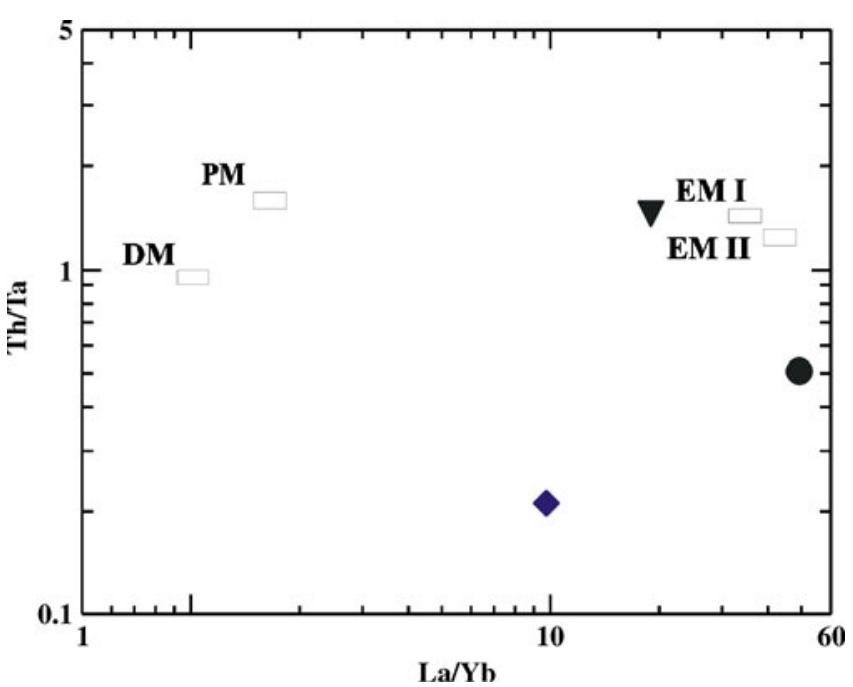

Figure 7. Th/Ta vs. La/Yb (Condie 1997) plot showing EM I and EM II sources for the MNS and melanite syenite rocks of the Sung valley and Jesra mafic-alkaline complex. Symbols are same as in figure 4 .

rock, representing the latter differentiated unit of the complex (Choudhuri et al 2009), shows similar OIB normalized trace element pattern with the host gabbro (figure 5). While, the OIB normalized trace element pattern of MNS is very similar to the garnet nepheline syenite of Sung alkaline ultramafic complex with characteristic enrichment of LILE and positive $\mathrm{Nb}$ anomaly. Plots of trace element data of $\mathrm{MNS}$ in $\mathrm{Nb} / \mathrm{Y}$ vs. $\mathrm{Zr} / \mathrm{Y}$ biaxial diagram (figure 6, after Riley et al 2005) is showing close to the enriched source. Th/Ta vs. La/Yb plot (figure 7, after Condie 1997) showing an EM I and EM II mantle sources for the MNS. So, the chemico-mineralogical character of the Mawpyut 
dyke rock suggests a source similar to that of Sung valley and Samchampi.

\section{Conclusion}

The petrological characters of MNS minor intrusion of Mawpyut reveal the following contrasting points in comparison to its host mafic-ultramafic rocks and the other alkaline complexes of the region.

- The mineralogy and mineral chemistry of MNS dyke rocks is different from that of its host maficultramafic rock and similar to melanite nepheline syenite rocks of Sung, Samchampi igneous complexes (Srivastava and Sinha 2007a, 2007b; Saha et al 2011). Melanite is stable for wide range of temperature and pressure and formed by late stage metasomatic reaction of mafic minerals with alkaline fluid, evidenced by its close spatial relation with the pyroxene in the petrographic study.

- The differentiated litho-units from ultramafic to mafic to monzonite/granite of Mawpyut, proposed by Chaudhuri et al (2009) are sub-alkaline in character whereas, the MNS dyke rock is in alkaline character (figure 3, Irvine and Barager 1971). Further, higher $\mathrm{K}_{2} \mathrm{O} / \mathrm{Na}_{2} \mathrm{O}$ ratio of MNS also shows resemblance with the nepheline syenite and ijolite rocks of Sung, Samchampi and Jesra.

- Trace element characteristics also denote enriched source for MNS dyke rock (figures 5 and 6) for MNS in contrast, the host mafic and ultramafic flat OIB normalized pattern (figure 6) and sources close to primodial mantle (PM).

- Isotopic studies using $\mathrm{Sr}-\mathrm{Nd}$ systematics reveal that in Sung (Srivastava and Sinha 2007a, 2007b) and Samchampi (Saha, pers. communication), the associated litho-units are not petrogenetically consanguineous. Moreover, the authors have expressed enriched melt compositions of EM I or EM II origin for the MNS rocks (figure 7).

- The above evidences indicate that the MNS dyke rock and the mafic-ultramafic host rocks of Mawpyut complex are the product of different melt composition and are possibly not co-genetic, suggested in other alkaline complexes in the region by the different workers.

- Kaergulian Ocean Island basalt is linked with the magmatic activity of the Sung valley alkalinecarbonatite complex (Srivastava et al 2005). MNS represents the late stage LILE enriched melt, contemporaneous with the alkaline rocks of the Sung-Samchampi alkaline complexes related to Kaergulian plume activity.

\section{Acknowledgements}

The authors are thankful to Sri Mukul Tiwari, Dy. D G and Head, Mission - IV, GSI for his encouragement on the fundamental research and active support for writing this paper.

\section{References}

Bilham R and England P 2001 Plateau 'pop-up' in the great 1897 Assam earth quake; Nature 401 806-809.

Bindi L, Cellai D, Melluso L, Conticelli S, Morra V and Menchetti S 1999 Crystal chemistry of clinopyroxene from alkaline undersaturated rocks of the Monte vulture volcano, Italy; Lithos 46 259-274.

Biswas S and Grasemann B 2005 Quantitative morphotectonics of the southern Shillong Plateau (BangladeshIndia); Australian J. Earth Sci. 97 82-103.

Chakraborti M K 1984 Petrology of Mundwara subvolcanic suite, Sirohi district, Rajasthan; Quart. J. Geol. Min. Met. Soc. India 56 138-156.

Chattopadhyay N and Hashmi S 1984 The Sung Valley alkaline-ultramafic-carbonatite complex, East Khasi Hills district, Meghalaya; Rec. GSI 113(4) 24-33.

Choudhuri S, Saha R, Ray J S and Bhaduri S 2009 Mawpyut intrusive complex of Jaintia Hill district, Meghalaya, Northeastern India; Geol. Soc. India 74 385-394.

Coffin M F, Pringle M S, Duncan R A, Gladezenko T P, Storey M, Muller R D and Gahagan L A 2002 Kerguelen hotspot magma output since $130 \mathrm{Ma}$; J. Petrol. 43 1121-1139.

Condie K C 1997 Sources of Proterozoic mafic dyke swarms: Constraints from $\mathrm{Th} / \mathrm{Ta}$ and $\mathrm{La} / \mathrm{Yb}$ ratio; Precamb. Res. $813-14$.

Cox K G, Bell J D and Pankhurst R J 1979 The interpretation of igneous rocks; George Allen \& Unwin, London, $450 p$.

Evans P 1964 The tectonic framework of Assam; Geol. Soc. India 5 80-96.

Gawalani L G, Rock N M S, Ramaswamy R, Griffin B J and Mulai B P 2000 Complexly zoned Ti-rich melanite schorlomite garnets from Ambardongar carbonatite complex, Deccan Igneous province, Gujrat State, western India; J. Asian Earth Sci. 18 163-174.

Ghosh S, Chakraborty S, Paul D K, Bhalla J K and Bishui P K 2005a New Rb-Sr isotopic ages and geochemistry of granitoids from Meghalaya and their significance in middle and late proterozoic crustal evolution; Indian Minerals $4833-44$

Ghosh S, Fallick A E, Paul D K and Potts PJ 2005b Geochemistry and origin of Neoproterozoic granitoids of Meghalaya, Northeast India: Implication for linkage with amalgamation of Gondwana Supercontinent; Gondwana Res. 8 421-432.

Gupta R P and Sen A K 1988 Imprints of Ninety East Ridge in the Shillong Plateau, Indian shield; Tectonophys. 154 $335-341$.

Irvine T N and Barager W R A 1971 A guide to chemical classification of common volcanic rocks; Canadian J. Earth Sci. 8 523-548.

Kumar D, Mamallan R and Dwivedy K K 1996 Carbonatite magmatism in northeast India; J. SE Asian Earth Sci. $13145-158$.

Locock A J 2008 An Excel spreadsheet to recast analysis of garnet to end members components, and a synopsis of crystal chemistry of natural silicate garnets; Computer Geosci. 34 1769-1780. 
Maitra M 1992 Petrology of the igneous suit of rocks along Sung Mawpyut areas, East Khassi and Jaintia Hills District, Meghalaya; Rec. GSI 125(4) 124-125.

Maitra M 2003 Petrology of the alkaline plugs in Patch Island, Kachhah District, Gujarat; Indian J. Geol. 75(1-4) 167-190.

Maitra M, Pant N C and Bhaduri S 2003 Ultramafic-mafic rock ensemble of Mawpyut, Jaintia Hill district, Meghalaya - a preliminary account; Indian Minerals 57(1-2) 75-84.

Melluso L, Srivastava R K, Guarino V, Zanetti A and Sinha A K 2010 Mineral compositions and petrogenetic evolution of the ultramafic-alkaline-carbonatitic complex of Sung Valley, Northern India; Canadian Mineralogist 48 205-229.

Mitra S K and Mitra S C 2001 Tectonic setting of the Precambrian of the north-eastern India (Meghalaya Plateau) and age of Shillong Group of rocks; Geol. Surv. India Spec. Publ. 64 653-658.

Morimoto M, Fabrics J, Ferguson A K, Ginzburg I V, Ross M, Scifert F A and Zussman J 1988 Nomenclature of pyroxenes; Mineral. Mag. 52 535-550.

Nag S, Sengupta S K, Gaur R K and Abser A 1999 Alkaline rocks of Samchampi-Samteran Karbi-Anglong district, Assam, India; J. Earth Syst. Sci. 108 33-48.

Nambiar A R 1988 Petrology of laprophyres from East Garo Hills and West Khasi Hills district, Meghalaya; J. Geol. Soc. India 32 125-132.

Rajendran C P, Rajendran K, Duarah B P, Baruah S and Earnest A 2004 Interpreting the style of faulting and paleoseismicity associated with the 1897 Shillong, north-east India, earth quake: Implications for regional tectonics; Tectonics $\mathbf{2 3}$ TC 4009.

Riley T R, Leat P T, Curtis M L, Millaar I L, Duncan R A and Fazel A 2005 Early middle Jurassic dolerite dykes from western Dronning Maud Land (Antarctica) identifying the mantle sources in the Karoo large igneous province; J. Petrol. 46 1489-1524.

Saha A, Ganguly S, Ray J and Chatterjee N 2010 Evalution of phase chemistry and petrochemical aspects of Samchampi-Samteran differentiated alkaline complex of Mikir Hills, northeastern India; J. Earth Syst. Sci. 119(5) 675-699.
Saha A, Ray J, Ganguly S and Chatterjee N 2011 Occurrence of melanite garnet in syenite and ijolite-melteigite rocks of Samchampi-Samteran alkaline complex, Mikir Hills, northeastern India; Curr. Sci. 101 95-100.

Sarkar A, Dutta A K, Poddar B C, Kollapuri V K, Bhattacharya B K and Sanyal R 1992 Geochronological studies of early Cretaceous effissive and intrusive rocks from north eastern India; In: Prog. and Abst. Mesozoic magmatism of the eastern margin of India (ed.) Ghosh N C, pp. 28-29.

Srivastava R K, Heaman L M, Sinha A K and Sinha S 2005 Emplacement age and isotope geochemistry of Sung Valley Alkaline Carbonatite complex, Shillong plateau, Northeastern India: Implications for primary carbonate melt and genesis of the associated silicate rocks; Lithos 81 33-54.

Srivastava R K and Sinha A K 2007a Nd and Sm isotope systematics and geochemistry of plume related alkalinemafic-ultramafic igneous complex from Jesra, Shillong Plateau, northeastern India; Geol. Soc. Am. Spec. Paper $430815-830$.

Srivastava R K and Sinha A K 2007b Petrogenesis of early Cretaceous ultramafic-mafic-alkaline-carbonatite igneous complexes from the Shillong plateau, NE India; In: Igneous petrology: 21st Century perspective (eds) Ray J S, Bhattacharyya C, pp. 143-164.

Strekeisen A 1976 To each plutonic rock its proper name; Earth Sci. Rev. 12 1-33.

Sun S and Mc Donough W F 1989 Chemical and isomatic systematics of oceanic basalts: Implication for mantle composition and processes; In: Magmatism in the ocean basins (eds) Saunders A D, Norry M J, Blackwell Science Publishers, 42 313-345.

Taylor S R and McLennan S M 1985 The Continental Crust: Its composition and evolution; Blackwell Science Publication, 312p.

Wilson M 1989 Igneous petrogenesis; Unwin Hyman, 466p.

Yin A, Dubey C S, Webb A A G, Kelty T K, Grove M, Gehrels G E and Burgess W P 2010 Geologic correlation of the Himalayan orogen and Indian craton: Part 1. Structural geology, U-Pb zircon geochronology and tectonic evolution of the Shillong Plateau and its neighboring regions in NE India; Geol. Soc. Am. Bull. 122(3-4) $336-359$. 